\title{
The Impact of Wage Bargaining Regime on Firm- Level Competitiveness and Wage Inequality: The Case of Ireland
}

\author{
Seamus McGuinness ${ }^{*}$, Elish Kelly and Philip O’Connell \\ Economic and Social Research Institute (ESRI) \\ Whitaker Square \\ Sir John Rogerson's Quay \\ Dublin 2 \\ Ireland
}

Abstract: This paper uses a linked employer-employee dataset to analyse the impact of institutional wage bargaining regimes on levels of average labour costs and within firm wage dispersion in private sector companies in Ireland. The results show that while centralised bargaining reduced labour costs within both the indigenous and foreign-owned sectors, the relative advantage was greater among foreign-owned firms. The analysis suggests that there are potentially large competitiveness gains to multinational companies that choose to locate in countries implementing a centralised bargaining system. Furthermore, the results provide additional support to the view that collective bargaining reduces within firm wage inequality.

Key Words: Wage Bargaining Regimes, Labour Costs, Wage Dispersion, Ireland.

JEL Classification: J51, J52, J58.

Corresponding Author: Seamus.McGuinness@esri.ie

*We are grateful to the Central Statistics Office (CSO) for access to the data used in this study. 


\section{The Impact of Wage Bargaining Regime on Firm-Level Competitiveness and Wage Inequality: The Case of Ireland}

\section{Introduction}

This paper uses a linked employer-employee dataset to analyse the impact of institutional wage bargaining arrangements on levels of average labour costs and within firm wage dispersion in private sector corporations in Ireland. Average labour costs are taken as a proxy measure for firm-level competitiveness, while dispersion measures the extent of wage inequality within the firm. Average labour costs can be thought of as a health measure relating to both the firm and, by extension, the wider economy, while dispersion relates more closely to employee wellbeing and, more particularly, the relative position of low paid workers in firms operating within one of the fastest growing OECD economies.

It is important to note that the questions addressed here go beyond that of the impacts of trade union membership on firm-level performance and inequality as, due the nature of wage bargaining arrangements in Ireland, and continental Europe more generally, the proportion of workers covered by collective bargaining regimes far exceeds the proportion who are members of trade unions (Hartog, 2002). While collective wage bargaining processes will be the primary channel through which trade unions impact wage levels, this is not to say that there are no additional influences deriving from firm trade union density. However, within a multivariate framework these additional influences can be thought off as separate to those derived from the wage bargaining process itself. This paper adds to the limited literature in this area by considering theses issues within an Irish context. The study also provides some assessment of the extent to which the impact of wage bargaining regimes differs across privately-owned indigenous firms and multinational companies (MNC's).

\section{Context and Literature}

Since 1987, wage bargaining in Ireland has been centralised at the national level, through a process known as Social Partnership. This partnership approach, which 
involves voluntary negotiations between the Government, main employer bodies and trade unions ${ }^{1}$, was introduced by the Government at this time to assist it in moving the country out of the bleak economic situation that it found itself in; a period characterised by high inflation, weak economic growth and, subsequently, considerable unemployment, mass emigration and unsustainable government borrowing and national debt ${ }^{2}$. There have been nine agreements to-date ${ }^{3}$, each of which has been tailored to medium term national economic and social needs, and has often built on its predecessor. Initially, pay and wage issues were the core elements of the negotiated agreements; specifically moderate wage increases in exchange for reductions in income tax to boost take-home pay. However, as the country recovered and moved into the 'Celtic Tiger' era, the partnership nature of the agreements became deeper and their coverage was extended to include various social and welfare issues that either emerged or become more prominent as the economy prospered.

The national pay agreements that have been negotiated through Social Partnership have been identified in a number of studies (Sexton \& O'Connell (1996), Lane (1998), Sweeney (1998), Aust (1999), O’Donnell (1999), Hardiman (2000), Teague \& Donaghey (2004), Baccaro \& Simoni (2007), O’Donnell (2008)) as having played an important role in the remarkable revival in the Irish economy that has taken place in the last two decades ${ }^{4}$. In particular, most of this research indicates that the wage restraint attained under the pay agreements enhanced the country's competitiveness, through lower labour costs, and this consequently led to both significant employment and economic growth. Figure 1 illustrates that real unit labour costs in Ireland have fallen in most years since the Social Partnership process began in 1987, and are well below those in the rest of the European Union (EU) and United States. Over the 19872002 period, unit labour costs fell by around 25 per cent in Ireland compared to,

\footnotetext{
${ }^{1}$ In 1996 the Government extended the list of social partners eligible to participate in the negotiation of national agreements to include various voluntary and community groups.

${ }^{2}$ Ireland had one of the highest budgetary deficits in the European Community (EC) in 1987, 10.7 per cent of Gross National Product (GNP). In addition, it had a national debt in excess of $120 \%$ of GNP, an unemployment rate of 18.5 per cent, net emigration close to 30,000 (which was equivalent to the natural increase in the population at this time), GDP per capita that was only 64 per cent of the EC average and very high interest rates (Department of the Taoiseach, 1987).

${ }^{3}$ The most recent was agreed in October-November 2008.

${ }^{4}$ In the Netherlands, a form of corporatism, similar to Ireland's Social Partnership model, has been identified with having contributed significantly to the 'Dutch Miracle' (Visser \& Hermerijck, 1997; Visser, 1998).
} 
approximately, 10 per cent across the EU. Thus, this would seem to suggest that the wage increases that have been attained under Social Partnership have been modest enough to boost Ireland's international competitiveness.

Furthermore, a few authors (for example, Lane (1998) and Aust (1999)) have suggested that, in addition to Ireland's low corporation tax rate and highly educated workforce, some MNC's were attracted to locate in Ireland because of its improved cost competitiveness, along with the relatively stable industrial relations environment that Social Partnership gave rise to. The attraction of MNC's to Ireland through foreign direct investment (FDI $)^{5}$, has also been identified as having played a very important role in Ireland's economic transformation (see, for example, Barry (1999), Barry et al. (1999) and OECD (1999, 2008)), and it continues to be a significant contributor to the economy's performance through both output and employment. For example, the number of individuals employed in manufacturing in MNC's in Ireland has grown from almost 74,000 in 1986 to 109,000 in 2005, a 48 per cent increase. Thus, MNC's share of total manufacturing employment in Ireland has increased over this period from 35 to just under 50 per cent (Figure 2) ${ }^{6}$. Finally, Tansey (1998) and Gunnigle \& McGuire (2001) also raise the possibility that centralised bargaining has helped improve the competitiveness of multinationals in Ireland.

While the literature has alluded to the benefits of Social Partnership in Ireland's recent economic success, specifically through the national wage agreement (NWA) component of the process, due mainly to a lack of data, there appears to be no previous empirical analysis of its direct impact on Ireland's competitiveness ${ }^{7}$.

\footnotetext{
${ }^{5}$ The term MNC's and FDI are used interchangeably throughout the paper.

${ }^{6}$ This employment data came from the Census of Industrial Production (CIP), which is produced by the Central Statistics Office (CSO), and 2005 is the most recent year for which data is available. Unfortunately, we do not have data from this source on nationality of ownership for the services sector. However, data available from Forfás (Ireland's national policy and advisory board for enterprise, trade, science, technology and innovation) indicates that the number of individuals employed in FDI-owned services companies increased from 2,945 in 1986 to 153,508 in 2007, a growth of 52 per cent (Forfás, 1995, 2007). This data, however, only relates to FDI firms that received government support and, therefore, will underestimate the total.

${ }^{7}$ Fitzgerald $(1999,2000)$, however, looked at wage formation in Ireland between 1962 and 1994, using national aggregate data, and concluded that the slow down in real wage growth observed after 1980 was due to "market forces" as opposed to centralised wage bargaining. He argued instead that the main contribution of Social Partnership to Ireland's economic turnaround has been in bringing about
} 
However, there are grounds to believe that Social Partnership will lead to lower labour costs, particularly for MNC's. Leahy \& Montagna (2000) develop a theoretical framework which predicts that MNC's may prefer to locate in countries with centralised bargaining, due to the gain in competitiveness associated with wage setting aimed at securing the interests of domestic firms. In the model, unions will choose to limit the rent extracted from the MNC in order to preserve employment levels in the less competitive domestic firms. Leahy \& Montagna (2000) argue that there may be a welfare loss to the economy in situations where the MNC's compete directly with domestic firms; however, they suggest that this is unlikely to be the case in Ireland where FDI has mainly occurred in sectors that did not have a substantial domestic component. Baccaro \& Simoni (2007) also argue convincingly that by linking wage growth in the high value added MNC's sector with that in the less competitive domestic component of the Irish economy, centralised wage bargaining, through the NWA, will have substantially enhanced the competiveness levels of MNC's. However, the authors only provide some descriptive support for their $\operatorname{argument}^{8}$.

In relation to wage dispersion, a number of studies have shown that countries with centralised wage bargaining have significantly lower levels of earnings inequality (OECD, 1997). These results have led to some degree of acceptance of the hypothesis that coordinated wage bargaining limits growth in inequality. Thus, a potential secondary impact of Social Partnership, and more specifically its NWA component, may have been to reduce earnings inequality. However, the evidence for Ireland is somewhat mixed. Barrett et al. (1999) found that there was a large growth in earnings dispersion in Ireland between the commencement of Social Partnership in 1987 and 1994. The authors concluded that centralised wage setting was not sufficient to limit the growth in earnings inequality. Further analysis by Barrett et al. (2002) demonstrated that wage inequality stabilised in the mid-1990s, a result they attributed in part to a marked increase in high-skilled inward migration. More recently, McGuinness et al. (2009) found that wage inequality fell for Irish men between 1994

industrial peace as opposed to moderating wage increases, and hence improving the country's competitiveness (see also Bradley et al., 1991).

${ }^{8}$ While not explicitly reporting a link with competitiveness, Radulescu \& Robson (2006) report some tentative evidence that co-ordinated wage bargaining systems can help reduce any deterrent effect of high levels of trade union density on MNC's location decision. 
and 2001, and for females between 1997 and 2001. The authors partially attributed the female result to the introduction of the minimum wage in 2000, a policy measure that was introduced through Social Partnership. However, while McGuinness et al. (2009) do not directly address the issue, it cannot be ruled out that the reduction in wage inequality observed over the period in question may be due, in part, to centralised wage bargaining.

From a wider international perspective, while there is a great deal of literature relating to trade union effects on earnings, both in the context of a wage premium (Freeman \& Medoff (1981), Lewis (1986), Stewart (1987), Schumacher (1999), Forth \& Millward (2002)) and wage dispersion (Freeman (1982), Blau \& Kahn (1996) DiNardo et al. (1996), Card et al. (2003), Dustmann \& Schönberg (2004)), much less is known with respect to the impact of bargaining regimes on firm-level wage dispersion and even less on measures of firm competitiveness ${ }^{9}$. Existing evidence is mostly restricted to European countries, presumably due both to the absence of such institutional arrangements elsewhere in the world and/or a lack of available data. Regarding wage inequality, for Germany, Gerlach \& Stephan (2005) found, for blue collar workers, lower levels of dispersion in firms implementing industry-level agreements ${ }^{10}$, while Kohn \& Lembake (2007) reported that industry and firm-level bargaining resulted in lower levels of wage dispersion relative to individual-level bargaining. Domínguez et al. (2004) found that firm-level agreements had a negative impact on firm-level wage dispersion in Spain compared to industry-level agreements. Finally, Plasman et al. (2007), who examined bargaining regimes in Belgium, Demark and Spain, reported higher (lower) levels of wage inequality associated with firm-level bargaining in Belgium and Denmark (Spain), and argued that this disparity in results may be accounted for by cross-country variations in the goals of trade unions.

Turning to the impact of bargaining regime on average labour costs, Kohn \& Lembake (2007) found higher average wages in German firms implementing both firm and industry-level agreements. Again for Germany, Guertzgen (2006) compared

\footnotetext{
${ }^{9}$ There is also an extensive body of research that looks at the impact of collective bargaining regimes on macroeconomic performance indicators. Aidt \& Tzannatos (2008) provide a recent systematic review of the empirical research in this area, along with the relevant theoretical literature.

${ }^{10}$ See also Stephan \& Gerlach (2005).
} 
the impacts of industry and firm-level agreements and found a small wage premium for industry-level bargaining in West Germany and firm-level bargaining in the East. Some further evidence can be taken from the impact of bargaining on individual wage outcomes; Card \& De la Rica (2006) reported a premium to individuals covered by firm-level bargaining in Spain relative to those covered by industry agreements. Plasman et al. (2007) also found that in Belgium, Denmark and again for Spain, that firm-level agreements resulted in a wage premium relative to workers covered by industry-level bargaining.

\section{Data and Methods}

The data used in this study comes from the 2003 National Employment Survey (NES). The 2003 NES is a matched employer-employee workplace survey, covering both the public and private sectors, which was carried out by the Irish Central Statistics Office $(\mathrm{CSO})^{11}$. The employer sample was drawn from the CSO's Central Business Register. Selected firms were then asked to extract a systematic sample of employees from their payrolls. Approximately 6,500 private sector employers and 300 public sector bodies were surveyed across the economy. Within this, a total sample of 60,000 employees were included from the private sector and 29,000 from the public sector. In total 54,000 returns were received.

The employer questionnaire requested information on employee earnings ${ }^{12}$, hour's worked and occupation. Information was also obtained on ownership type ${ }^{13}$, firm size, industry, use of pay agreements, percentage of employees covered by the minimum wage and provision of certain employee benefits, specifically career breaks and worksharing and/or part-time work. With respect to the pay agreements information,

\footnotetext{
${ }^{11}$ Only employers with more than three employees were surveyed and the data were collected at the enterprise level. While the NES was of enterprises with 3 plus employees, the results were calibrated to the Quarterly National Household Survey (QNHS) employment data for employees (excluding agriculture, forestry and fishing), which covers all employees.

${ }^{12}$ The earnings information collected in the 2003 NES represents the gross monthly amount payable by the organisation to its employees, and relates to the month of March in 2003. This includes normal wages, salaries and overtime; taxable allowances, regular bonuses and commissions; and holiday or sick pay for the period in question. It does not include employer's Pay Related Social Insurance (PRSI), redundancy payments and back pay.

${ }^{13}$ The "ownership" variable allows us to distinguish public and private sector organisations, and, inter alia, within the private sector between indigenously owned and subsidiaries of foreign companies.
} 
employers were asked to indicate the proportion of their workforce covered by the following types of agreement:
i) Individual-level
ii) Business-level
iii) Industry-level
iv) National-level (NWA)
v) Other

Clearly, business, industry and national-level represent the various types of collective wage bargaining.

Employees were issued with a separate questionnaire within which they provided information on their age, gender, educational attainment, family status, employment status (part-time or full-time), length of time in paid employment, length of service with current employer and also other job-related characteristics (for example, trade union membership, shift-work, supervisory role, and flexi hours).

The dataset at hand does not allow an assessment of the impacts of bargaining agreements on individual-level earnings as we cannot be certain (below a 100 per cent threshold) that a specific form of wage bargaining covers an individual. Given this, the key aim of this paper is to assess the impact of institutional wage bargaining on firm-level average labour costs and wage inequality. To assess the impact of bargaining on average labour costs, we retain one observation per firm and derive a number of variables that we use to explain both average labour costs and wage dispersion. We apply establishment-level weights to these firm-level observations to ensure that our results are representative. Given that the NWA is the governing wage bargaining strategy used in the public sector in Ireland, suggesting little variation in this component of the data, the study is restricted to private sector firms. Once this adjustment is made to the data we are left with a sample of 3,755 firms employing 275,570 employees. Of the firm sample, 414 are MNC's and 3,341 indigenous firms, each respectively employing 93,025 and 182,545 individuals. 
An advantage of focussing on firm-level impacts is that while it is not certain that statistically significant individual-level wage effects translate to comparable firmlevel effects, we can be more confident that any firm-level impact will be indicative of the wage consequences for the majority of relevant workers within the firm. More importantly, from a policy perspective this approach also allows us to assess the extent to which average labour costs are affected by wage bargaining arrangements and therefore their potential impact on competitiveness.

In addition to average wage level impacts, we also assess the effect of various forms of bargaining on wage dispersion within the firm. A priori, we would expect firms implementing forms of collective bargaining to have more compressed wage distributions; however, it is less clear to what extent wage compression varies by the mode of collective bargaining. As a dependant variable in this analysis we opt for the coefficient of variation as such a dimensionless measure is preferable when making comparisons across firms with widely varying wage distributions.

\section{Results}

The following section provides a descriptive assessment of the extent to which modes of wage bargaining vary by firm size, ownership (foreign versus indigenous) and sector.

The first column in Table 1 looks at the average coverage rate of the various types of agreement across all private sector firms. Individual-level agreements constitute the dominant wage bargaining mechanism in the private sector with, on average, 49 per cent of employees within the typical firm covered by such agreements. The average coverage level of the NWA was 30 percent, while industry and business-level agreements each had an average coverage level of less than 10 per cent ${ }^{14}$. However, the average in this case is misleading as it is not the case that firms typically implement a mix of different types of agreement. Specifically, as the second column of Table 1 indicates, within firms' one form of wage agreement tends to dominate.

\footnotetext{
${ }^{14}$ Due to differences in the average employment size of firms implementing various forms of bargaining, these figures will not correspond to the percentage of the workforce covered by each type of agreement.
} 
For instance, for those firms implementing the NWA to any degree, the average coverage rate within the firm is just below 90 per cent. This point is further illustrated by the fact that taking a 70 per cent employment coverage cut-off point, only 12.3 per cent of firms do not implement a single form of agreement above this level. The remaining distribution of firms implement the various forms of agreement at the 70 per cent cut-off point were as follows: 43 per cent for an individual-level agreement, 28 per cent the NWA, 7 per cent for both business-level and industry-level agreements and 2 per cent for other. Consequently, given that the overwhelming majority of firms adopt a particular form of wage agreement for more than 70 per cent of their workforce, we use cut-off points as the baseline for the analysis undertaken in the paper. The 12.3 per cent of firms not implementing a single bargaining strategy above the 70 cut-off point forms the comparison group for the study, which we consequently refer to as the 'no majority' grouping.

Table 2 reports the average proportion of employees covered by each bargaining arrangement by firm size at the 70 per-cent employment coverage cut-off point. Perhaps, not surprisingly, individual-level bargaining is more heavily implemented by smaller firms, while collective bargaining arrangements, in particular the NWA are, on average, more heavily implemented by firms employing more than 50 workers. These results suggest that the share of the workforce employed under the NWA (individual agreements) will be higher (lower) than the proportions reported in Table 1.

With respect to sector, and adopting a similar interpretation as in Table 2, Table 3 shows that individual-level bargaining is dominant in the Business Services and Transport \& Communications sectors, the NWA is somewhat over-represented in Manufacturing, while industry-level agreements are most important within the Construction sector.

Finally, Table 4 looks at the incidence of bargaining agreement by ownership type. Interestingly, while the generally accepted view suggests that MNC's are more likely to adopt individual-level bargaining and are, therefore, less inclined towards collective forms of wage determination, the results suggest that the opposite is in fact the case in the Irish context. MNC's were found to be somewhat less likely to 
implement individual-level bargaining at the 70 per cent threshold, and were more likely to adopt the NWA and business-level agreements relative to indigenous firms.

\section{Multivariate Analysis}

Moving onto the econometric analysis, our specifications are based around the assumption that just as individual-level wages are primarily determined by the amount of human capital accumulated, average labour costs within the firm will be driven by the education profile of the workforce. Such factors are also important with respect to earnings inequality, as we would expect the distribution to be more dispersed in firms employing workers across a range of skill levels. Give this, we estimate the following:

$$
\begin{gathered}
\bar{Y}=\alpha+\beta_{1} \bar{H}+\beta_{2} F+\beta_{3} B g n+\varepsilon \\
\sigma=\alpha+\beta_{1} \bar{H}+\beta_{2} F+\beta_{3} B g n+\varepsilon
\end{gathered}
$$

where $\bar{Y}$ represents average firm labour costs, $\sigma$ represents the coefficient of variation, $\bar{H}$ the mean human capital characteristics of the workforce, $\mathrm{F}$ firm-level characteristics, Bgn the form of wage bargaining adopted with a coverage rate at/or above a specified cut-off point and $\varepsilon$ the error term. In terms of the human capital controls, where the individual-level information is based on a binary variable the firmlevel value is expressed as a share, otherwise an average value is included. The firmlevel controls included within the model relate to ownership type, trade union density, firm size, mode of production and sector.

Despite the earlier discussion, we are conscious of the fact that the method of wage bargaining may still be correlated, at least to some extent, with trade union density and the inclusion of this control in our model may serve to obscure the wage impacts of particular modes of bargaining. As a robustness check, we re-estimated the average labour cost models in a specification that excluded trade union density and the results hold. As an additional precautionary measure, we attempt to explicitly control for the possibility that our estimates could be prone to bias if the wage bargaining approach used is correlated with firm-level characteristics, such as trade union density, etc., that 
are in turn associated with higher/lower labour costs. To account for such effects we follow Card \& De La Rica (2006) by including the predicted probability (i.e. propensity scores) of adopting various forms of bargaining arrangements as controls within the firm-level regression.

We estimate our models at a series of cut-off points - 70, 80 and 90 per cent - to control for the possibility that the impacts become more pronounced the higher the agreement coverage level within the firm. We ensure that the base case remains consistent across the three specifications by excluding those firms with 70 to 79 per cent coverage from the 80 per cent regression and those firms with a 70 to 89 per cent coverage from the 90 per cent regression. Thus, the base case for our all models consists of the 12.3 per cent of firms that do not implement any single type of bargaining arrangement for more than 70 per cent of their workforce.

The results from the OLS average labour cost model with the bargaining variables constructed above the 70 per cent employment coverage cut-off point are reported in the first column of Table 5. The results indicate that, relative to the comparison group, average labour costs were 8.6 per cent higher in firms implementing individual-level agreements and 6.8 per cent higher in firms where wages are determined on the basis of business-level agreements. No wage impacts arose as a consequence of the NWA or industry-level bargaining. The results change little when the cut-off points are raised to 80 and 90 per cent respectively, while the inclusion of the propensity score variables increased the estimated impact by less than 5 per cent, which suggests that any bias relating to correlations with firm-level effects was relatively limited ${ }^{15}$. Perhaps, not surprisingly, the propensity score controls suggest that the NWA is more likely to be implemented in lower waged firms ${ }^{16}$. This finding that average labour costs are highest in firms not covered by collective bargaining arrangements suggests that, at least in the Irish Social Partnership context, the NWA acts as a benchmark for all other forms of collective bargaining as it constrains average pay growth within

\footnotetext{
${ }^{15}$ Interestingly the union density effect has fallen in terms of significance in the adjusted regression, suggesting that this factor may have been affecting the collective bargaining variables in the OLS model.

${ }^{16}$ To help ensure proper identification, we include two variables in our probit models, export intensity and share of employees working under flexible working arrangements, which are excluded from the wage equations. The coefficients and stand errors of the propensity score adjustments are presented in Table A1 in Appendix A.
} 
such firms to a level below that of firms not covered by collective arrangements. Regarding the other covariates, the coefficients all conform to expectations. Average labour costs were positively related with the education levels of the workforce, average experience, firm size, foreign ownership and trade union density and negatively correlated with the part-time employment share and the proportion of the workforce engaged in shift work. Finally, on the grounds that average labour cost impacts will reflect individual wage effects, Table 5 also suggests that individuals employed in firms where trade unions bargain directly with the employer do considerably better than those in similar firms where the trade union opts for wage bargaining through the NWA framework.

Table 6 reports the results from the wage dispersion regressions. The models are again well specified with wage dispersion increasing with the share of educated labour, and higher in larger firms and those in the foreign-owned sector. As expected, within firm wage inequality was inversely related to levels of trade union density. In addition, the higher the proportion of the workforce made up of part-time and shift workers the lower the level of wage dispersion, reflecting the fact that wage levels will vary less in firms with high proportions of relatively low skilled workers. Even after controlling for the effects of trade union density, we still find that bargaining arrangements have differential impacts on the wage distribution. The results indicate that wage inequality is lower in firms implementing the NWA or industry-level agreements, providing further support for the view that collective bargaining arrangements reduce within firm levels of wage inequality. However, while the results are only significant at the 10 per cent level, they are relatively stable with respect to the extent of agreement coverage.

Given the importance of the foreign-owned sector in Ireland, and the hypothesis linking FDI and collective wage bargaining frameworks, we examine the extent to which wage bargaining has differential impacts within this sector by introducing a series of FDI interaction terms into our average labour cost and dispersion models. The general assumption is that MNC's have a strong preference for a high degree of discretion regarding wage setting, which implies that they will tend not to locate in economies that have a heavily centralised wage bargaining system. 
The results from the average labour cost equation are reported in Table $7^{17}$. It should be noted that the base case for the model now becomes indigenous firms failing to implement any form of agreement above the 70 per cent threshold i.e. a range of agreements are being implemented ${ }^{18}$. Within the indigenous sector we again find that average labour costs are highest among those firms implementing individual and business-level agreements. However, the pattern is somewhat different among foreign-owned firms: within the foreign-owned sector average labour costs were highest among those implementing a range of agreements; however, in MNC's implementing the NWA average pay levels were almost 17 per cent below the base case. The results suggest that labour costs within such organisations are lowered more substantially than those of other MNC's implementing other types of agreements, and indeed the advantage appears to exceed that of indigenous firms implementing the NWA. The evidence suggests that MNC's implementing the NWA have average labour costs that not only fall below those of other multinationals but have tended towards convergence with those of the indigenous sector, which indicates that the competitive advantage from locating in a country with centralised bargaining go beyond those suggested by the Leahy \& Montagna (2000) model.

To further investigate this issue, we estimated an Oaxaca-Blinder decomposition (Oaxaca, 1973; Blinder, 1973), which allows us to assess the extent to which the labour cost differential between MNC's and indigenous firms is narrowed as a result of the NWA. The decomposition is standard and can be written as follows:

$\overline{L C_{M N C}}-\overline{L C_{I N D}}=\left(\overline{X_{M N C}}-\overline{X_{I N D}}\right) \beta_{M N C}+\left(\beta_{M N C}-\beta_{I N D}\right) \bar{X}_{I N D}+\left(\overline{\alpha_{M N C}}-\overline{\alpha_{I N D}}\right)$

where LC represents average labour costs, IND is firms in the indigenous sector, $\mathrm{X}$ is a vector of all characteristics (human capital, bargaining regime and firm-level) determining labour costs, $\beta$ is the return to these characteristics and $\alpha$ the intercept terms. The first term in the right-hand measures endowment effects i.e. the proportion of the gap attributable to characteristic differences, while the second term relates to coefficient effects i.e. difference returns to a given characteristic. We assume MNC's

\footnotetext{
${ }^{17}$ See Table A2 in Appendix A for the details on the propensity score variables.

${ }_{18}$ Such firms are more predominant within the FDI sector, accounting for 15 per cent of the distribution.
} 
to represent the non-discriminatory regime on the grounds that labour costs are higher in this sector; however, our results stand when we take the indigenous sector as the base. Furthermore, when estimating detailed decomposition of this nature, we must be aware of the identification problem associated with the use of dummy variables where the number of categorical dummies exceeds one (Oaxaca \& Ransom, 1999). In this paper, pay bargaining regime and sector are both potentially affected by this identification issue. We have applied the approach developed by Gardeazabal \& Ugidos (2004) to deal with this problem to the sector dummy variables in our model by estimating the decompositions imposing a normalising restriction ${ }^{19}$. However, due to the small number of MNC's implementing industry-level and other types of agreement, it was not possible to estimate the decomposition with the constraint imposed on the bargaining regime variables ${ }^{20}$. Consequently, we instead estimate the effects of bargaining regime using the original share values.

We can see from the results presented in Table 8 that the unadjusted average labour cost gap between MNC's and indigenous firms was 35.8 per cent, falling to 12.5 per cent once account was taken for differences in characteristics between both types of firms. Focussing on the impact on individual variables, the largest factor determining the cost gap is due to firms in the FDI sector being, on average, much larger in size. In addition, with respect to coefficient effects, the second major driver of the observed gap was the higher return to average experience in FDI firms. Most importantly, regarding bargaining regime, the results confirm that the adoption of the NWA among MNC's results in an average labour cost gap reduction of almost 6 per cent. In addition, the fact that individual-level agreements' tend to be more wage inflationary in the indigenous sector also serves to reduce the gap by a margin of just below 4 per cent. The analysis confirms our earlier assertion that the cost advantage to MNC's adopting the NWA exceeds that of indigenous firms. Finally, the analysis indicates that trade union density has a greater price effect on average labour costs among indigenous firms, which leads to a gap reduction of just over 2 per cent.

\footnotetext{
${ }^{19}$ The normalisation of the restriction on the coefficients can be written as follows: $\sum_{j=1}^{J} \beta_{j 8}=0$. The implementation of this restriction leaves the other coefficients unaffected.

${ }^{20}$ With respect to sector, the constraint was estimated.
} 
With respect to wage dispersion, the results are presented in Table 9 and the interpretation of the coefficients are as before with indigenous firms implementing an arrange of agreements representing the base case. The analysis suggests that in the indigenous sector, within firm earnings inequality was significantly lower in firms implementing industry-level agreements and the NWA. In the FDI sector, dispersion was lowest in firms implementing an arrange of wage bargaining arrangements and those implementing industry or national-level agreements. Thus, the pattern regarding wage dispersion is somewhat more consistent across ownership categories. However, as all effects are relative to a base case, the results indicate that the distributional effects of collective bargaining through industry and national agreements on wage dispersion are stronger within indigenous firms.

Finally, the analysis shows that MNC's implementing a range of agreements are a somewhat unique category, as they have high average labour costs and relatively low levels of dispersion. This suggests that such firms may be concentrating on specialist high value added activities such as R\&D. Consequently, the failure to separate out such firms within the OLS model serves to obscure the impacts of centralised bargaining on wage dispersion.

\section{Summary and Conclusions}

This paper examines the impact of various forms of wage bargaining on firm-level average labour costs and wage dispersion in private sector firms in Ireland. The results show that average labour costs were higher in firms implementing individual agreements and business-level bargaining, and that the NWA exerted a largely neutral influence on labour costs. The finding that average labour costs are highest in firms implementing individual-level agreements suggests that Social Partnership constrains the pay demands of all forms of collective bargaining below that of the non-covered sector. The research also indicates that MNC's implementing the NWA have average labour costs that fall below those of other multinationals and may indeed have begun to converge with those of indigenous firms. This result suggests that there are potentially large gains, in terms of competitiveness, to MNC's choosing to locate in countries implementing a centralised bargaining system. On a more conventional note, the results show that within firm wage dispersion is lower in both MNC's and indigenous firms 
implementing the NWA or industry-level agreements. However, the wage compression impacts of collective bargaining were found to be more pronounced in the indigenous sector. The analysis adds further support to the view that collective bargaining reduces within firm wage inequality. 


\section{Figures}

Figure 1: Index of Real Unit Labour Costs (Total Economy) 1987-2003 (Base Year=1987)

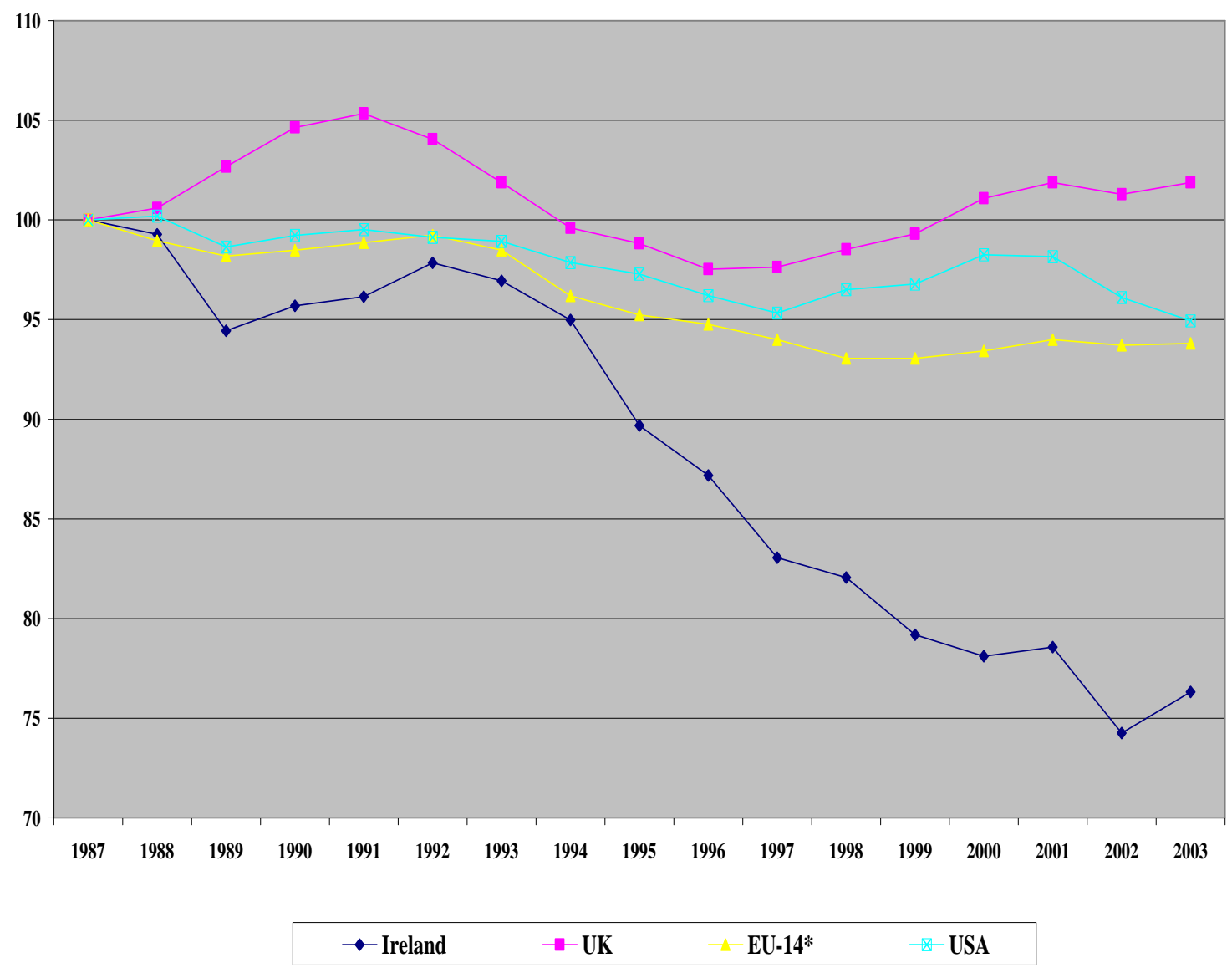

Note: * EU-15 with Luxembourg excluded

Source: Constructed with data from the European Economy, No.6, 2003 
Figure 2: Irish-owned and Foreign-owned Firms Share of Total Manufacturing Employment in Ireland: 1986-2005

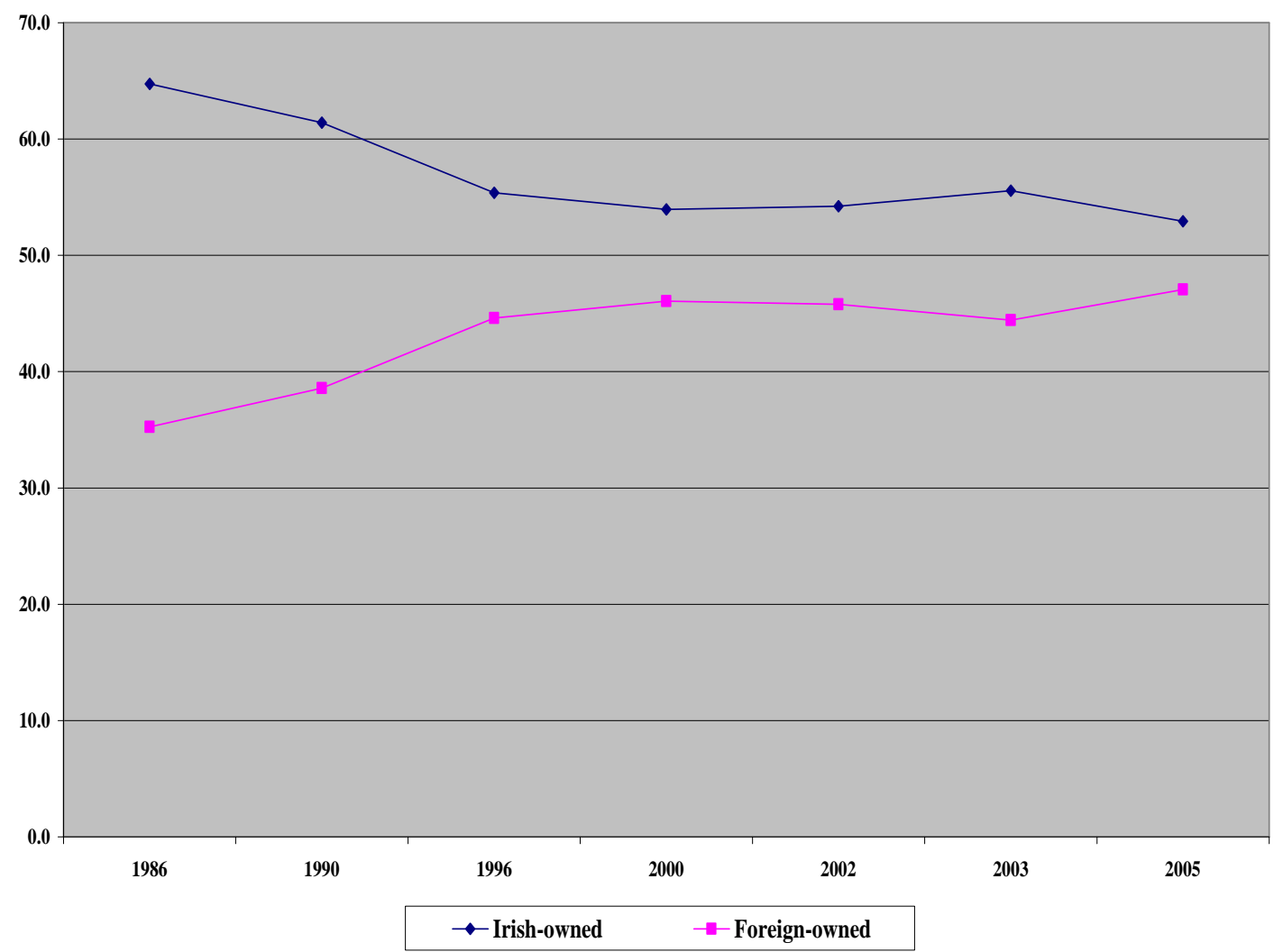

Source: Constructed with data from the Central Statistics Office's (CSO) Census of Industrial Production 
Tables

Table 1: Average Wage Agreement Coverage: Overall Coverage and Coverage for Firms Adopting a Specific Agreement

\begin{tabular}{lcc}
\hline Wage Agreement Type & Overall Coverage & $\begin{array}{c}\text { Coverage for Specific } \\
\text { Agreement }\end{array}$ \\
\hline Individual-level & 48.8 & 86.5 \\
Business-level & 6.8 & 83.1 \\
Industry-level & 8.3 & 80.5 \\
National-level & 29.7 & 88.5 \\
Other Type & 6.4 & 78.6 \\
\hline
\end{tabular}

Table 2: $\quad$ Wage Agreement Coverage by Firm Size (70\% Cut-Off Point)

Individual Business Industry National Other Type No Majority Number

\begin{tabular}{lccccccc}
\hline $\begin{array}{l}\text { Firm Size: } \\
0-9\end{array}$ & 53.3 & 5.2 & 6.2 & 23.9 & 2.4 & 9.1 & 1,591 \\
$10-19$ & 43.9 & 7.5 & 7.1 & 29.9 & 2.4 & 11.1 & 784 \\
$20-49$ & 32.4 & 7.5 & 9.2 & 33.2 & 2.2 & 15.9 & 611 \\
$50-99$ & 20.8 & 8.5 & 12.4 & 37.8 & 2.1 & 18.8 & 311 \\
$100+$ & 17.3 & 6.1 & 8.2 & 45.3 & 2.2 & 20.9 & 450 \\
Total & & & & & & & 3,747 \\
\hline
\end{tabular}


Table 3: $\quad$ Wage Agreement Coverage by Sector (70\% Cut-Off Point)

\begin{tabular}{|c|c|c|c|c|c|c|c|}
\hline & Individual & Business & Industry & National & $\begin{array}{l}\text { Other } \\
\text { Type }\end{array}$ & $\begin{array}{c}\text { No } \\
\text { Majority }\end{array}$ & Number \\
\hline Manufacturing & 33.5 & 6.5 & 5.0 & 39.7 & 1.3 & 14.4 & 442 \\
\hline Electricity* & - & - & - & - & - & - & - \\
\hline Construction & 36.9 & 3.4 & 24.7 & 23.7 & 1.6 & 10.0 & 449 \\
\hline Wholesale \& Retail & 49.2 & 6.9 & 4.9 & 24.0 & 2.3 & 13.0 & 887 \\
\hline Hotels \& Restaurants & 40.9 & 6.6 & 9.7 & 30.0 & 1.2 & 12.2 & 207 \\
\hline Transport \& Communications & 55.2 & 9.8 & 3.8 & 20.4 & 2.2 & 9.6 & 279 \\
\hline Financial Intermediation & 50.1 & 8.6 & 3.2 & 26.2 & 7.6 & 8.4 & 188 \\
\hline Business Services & 65.1 & 7.0 & 5.2 & 11.2 & 3.1 & 8.6 & 602 \\
\hline Education & 47.3 & 5.8 & 5.1 & 32.0 & 4.9 & 10.6 & 101 \\
\hline Health & 47.8 & 7.8 & 1.8 & 33.9 & 1.2 & 8.6 & 377 \\
\hline Other Services & 44.8 & 4.1 & 7.0 & 30.3 & 2.4 & 11.5 & 220 \\
\hline \multicolumn{8}{|c|}{ Note: ${ }^{*}$ Results cannot be reported for confidentiality reasons } \\
\hline \multicolumn{8}{|c|}{$\begin{array}{l}\text { Table 4: Wage Agreement Coverage in FDI Firms Relative to Non-FDI } \\
\text { Firms (70\% Cut-Off Point) }\end{array}$} \\
\hline Wage Agreement Type & & & & FDI & \multicolumn{3}{|c|}{ Non-FDI } \\
\hline Individual-level & & & & 40.0 & \multicolumn{3}{|c|}{46.1} \\
\hline Business-level & & & & 9.8 & \multicolumn{3}{|c|}{5.9} \\
\hline Industry-level & & & & 4.8 & \multicolumn{3}{|c|}{7.3} \\
\hline National-level & & & & 28.5 & \multicolumn{3}{|c|}{27.7} \\
\hline Other Type & & & & 2.4 & \multicolumn{3}{|c|}{23.2} \\
\hline No Majority & & & & 14.8 & \multicolumn{3}{|c|}{11.2} \\
\hline
\end{tabular}


Table 5:

Average Labour Cost Models

\begin{tabular}{|c|c|c|c|c|c|c|}
\hline Variable & $\begin{array}{l}\text { OLS } \\
70 \% \\
\end{array}$ & $\begin{array}{l}\text { Adjusted } \\
\text { OLS 70\% } \\
\end{array}$ & $\begin{array}{l}\text { OLS } \\
80 \% \\
\end{array}$ & $\begin{array}{l}\text { Adjusted } \\
\text { OLS 80\% } \\
\end{array}$ & $\begin{array}{l}\text { OLS } \\
90 \% \\
\end{array}$ & $\begin{array}{l}\text { Adjusted } \\
\text { OLS 90\% } \\
\end{array}$ \\
\hline Constant & $\begin{array}{c}1.850 * * * \\
(0.036)\end{array}$ & $\begin{array}{c}2.389 * * * \\
(0.183)\end{array}$ & $\begin{array}{c}1.858 * * * \\
(0.036)\end{array}$ & $\begin{array}{c}2.296 * * * \\
(0.184)\end{array}$ & $\begin{array}{c}1.859 * * * \\
(0.037)\end{array}$ & $\begin{array}{c}2.200 * * * \\
(0.185)\end{array}$ \\
\hline Average Experience & $\begin{array}{c}0.010 * * * \\
(0.001)\end{array}$ & $\begin{array}{c}0.011 * * * \\
(0.002)\end{array}$ & $\begin{array}{c}0.010 * * * \\
(0.001)\end{array}$ & $\begin{array}{c}0.011 * * * \\
(0.002)\end{array}$ & $\begin{array}{c}0.010 * * * \\
(0.001)\end{array}$ & $\begin{array}{c}0.010 * * * \\
(0.002)\end{array}$ \\
\hline Share of Part-Time Workers & $\begin{array}{c}-0.003^{* * *} * \\
(0.000)\end{array}$ & $\begin{array}{c}-0.003 * * * \\
(0.000)\end{array}$ & $\begin{array}{c}-0.003 * * * \\
(0.000)\end{array}$ & $\begin{array}{c}-0.003 * * * \\
(0.000)\end{array}$ & $\begin{array}{c}-0.003 * * * \\
(0.000)\end{array}$ & $\begin{array}{c}-0.003 * * * \\
(0.000)\end{array}$ \\
\hline Share of Junior Cert Quals & $\begin{array}{c}0.000 \\
(0.000)\end{array}$ & $\begin{array}{c}0.001 * * \\
(0.000)\end{array}$ & $\begin{array}{c}0.001 \\
(0.000)\end{array}$ & $\begin{array}{c}0.001 * * \\
(0.000)\end{array}$ & $\begin{array}{c}0.001 \\
(0.000)\end{array}$ & $\begin{array}{l}0.001 * \\
(0.000)\end{array}$ \\
\hline Share of Leaving Cert Quals & $\begin{array}{c}0.002 * * * \\
(0.000)\end{array}$ & $\begin{array}{c}0.003 * * * \\
(0.001)\end{array}$ & $\begin{array}{c}0.002^{* * *} * \\
(0.000)\end{array}$ & $\begin{array}{c}0.003 * * * \\
(0.001)\end{array}$ & $\begin{array}{c}0.002 * * * \\
(0.000)\end{array}$ & $\begin{array}{c}0.003 * * * \\
(0.001)\end{array}$ \\
\hline Share of Post Leaving Cert Quals & $\begin{array}{c}0.002 * * * \\
(0.000)\end{array}$ & $\begin{array}{c}0.001 * * \\
(0.001)\end{array}$ & $\begin{array}{c}0.002 * * * \\
(0.000)\end{array}$ & $\begin{array}{c}0.001 * * \\
(0.001)\end{array}$ & $\begin{array}{c}0.002 * * * \\
(0.000)\end{array}$ & $\begin{array}{c}0.002 * * \\
(0.001)\end{array}$ \\
\hline Share of Third-Level No Degree & $\begin{array}{c}0.005^{* * * *} \\
(0.000)\end{array}$ & $\begin{array}{c}0.005^{* * *} * \\
(0.001)\end{array}$ & $\begin{array}{c}0.005^{* * *} * \\
(0.000)\end{array}$ & $\begin{array}{c}0.005^{* * * *} \\
(0.001)\end{array}$ & $\begin{array}{c}0.005 * * * \\
(0.000)\end{array}$ & $\begin{array}{c}0.005 * * * \\
(0.001)\end{array}$ \\
\hline Share of Graduates & $\begin{array}{c}0.007 * * * \\
(0.000)\end{array}$ & $\begin{array}{c}0.008 * * * \\
(0.001)\end{array}$ & $\begin{array}{c}0.007 * * * \\
(0.000)\end{array}$ & $\begin{array}{c}0.009 * * * \\
(0.001)\end{array}$ & $\begin{array}{c}0.007 * * * \\
(0.000)\end{array}$ & $\begin{array}{c}0.008 * * * \\
(0.001)\end{array}$ \\
\hline Individual-level Agreement & $\begin{array}{c}0.086 * * * \\
(0.020)\end{array}$ & $\begin{array}{c}0.089 * * * \\
(0.020)\end{array}$ & $\begin{array}{c}0.080 * * * \\
(0.020)\end{array}$ & $\begin{array}{c}0.082 * * * \\
(0.020)\end{array}$ & $\begin{array}{c}0.080 * * * \\
(0.020)\end{array}$ & $\begin{array}{c}0.080 * * * \\
(0.020)\end{array}$ \\
\hline Business-level Agreement & $\begin{array}{c}0.068 * * \\
(0.029)\end{array}$ & $\begin{array}{c}0.071 * * \\
(0.029)\end{array}$ & $\begin{array}{c}0.060 * * \\
(0.030)\end{array}$ & $\begin{array}{c}0.063 * * \\
(0.030)\end{array}$ & $\begin{array}{l}0.055 * \\
(0.031)\end{array}$ & $\begin{array}{l}0.057 * \\
(0.031)\end{array}$ \\
\hline Industry-level Agreement & $\begin{array}{c}0.001 \\
(0.028)\end{array}$ & $\begin{array}{c}0.006 \\
(0.028)\end{array}$ & $\begin{array}{c}0.009 \\
(0.030)\end{array}$ & $\begin{array}{c}0.015 \\
(0.030)\end{array}$ & $\begin{array}{c}0.014 \\
(0.031)\end{array}$ & $\begin{array}{c}0.017 \\
(0.031)\end{array}$ \\
\hline National-level Agreement & $\begin{array}{c}0.012 \\
(0.021)\end{array}$ & $\begin{array}{c}0.017 \\
(0.021)\end{array}$ & $\begin{array}{c}0.006 \\
(0.021)\end{array}$ & $\begin{array}{c}0.012 \\
(0.021)\end{array}$ & $\begin{array}{c}0.007 \\
(0.021)\end{array}$ & $\begin{array}{c}0.010 \\
(0.021)\end{array}$ \\
\hline Other Type of Agreement & $\begin{array}{l}-0.004 \\
(0.042)\end{array}$ & $\begin{array}{l}-0.003 \\
(0.042)\end{array}$ & $\begin{array}{l}-0.020 \\
(0.043)\end{array}$ & $\begin{array}{l}-0.019 \\
(0.043)\end{array}$ & $\begin{array}{l}-0.022 \\
(0.044)\end{array}$ & $\begin{array}{l}-0.022 \\
(0.044)\end{array}$ \\
\hline Average Shift-work & $\begin{array}{c}-0.166^{* * *} * \\
(0.030)\end{array}$ & $\begin{array}{c}-0.135^{* *} \\
(0.054)\end{array}$ & $\begin{array}{c}-0.183 * * * \\
(0.030)\end{array}$ & $\begin{array}{c}-0.152 * * * \\
(0.050)\end{array}$ & $\begin{array}{c}-0.186 * * * \\
(0.031)\end{array}$ & $\begin{array}{c}-0.169 * * * \\
(0.048)\end{array}$ \\
\hline Average Professional Body & $\begin{array}{c}0.403 * * * \\
(0.036)\end{array}$ & $\begin{array}{c}0.303 * * * \\
(0.066)\end{array}$ & $\begin{array}{c}0.409 * * * \\
(0.036)\end{array}$ & $\begin{array}{c}0.304 * * * \\
(0.078)\end{array}$ & $\begin{array}{c}0.405 * * * \\
(0.037)\end{array}$ & $\begin{array}{c}0.349 * * * \\
(0.081)\end{array}$ \\
\hline FDI & $\begin{array}{c}0.187 * * * \\
(0.025)\end{array}$ & $\begin{array}{c}0.172 * * * \\
(0.036)\end{array}$ & $\begin{array}{c}0.189 * * * \\
(0.026)\end{array}$ & $\begin{array}{c}0.177 * * * \\
(0.035)\end{array}$ & $\begin{array}{c}0.181 * * * \\
(0.027)\end{array}$ & $\begin{array}{c}0.163 * * * \\
(0.036)\end{array}$ \\
\hline Firm Size & $\begin{array}{c}0.104 * * * \\
(0.007)\end{array}$ & $\begin{array}{c}0.089 * * * \\
(0.014)\end{array}$ & $\begin{array}{c}0.103 * * * \\
(0.007)\end{array}$ & $\begin{array}{c}0.093 * * * \\
(0.014)\end{array}$ & $\begin{array}{c}0.104 * * * \\
(0.008)\end{array}$ & $\begin{array}{c}0.092 * * * \\
(0.013)\end{array}$ \\
\hline Trade Union Density & $\begin{array}{c}0.001 * * * \\
(0.000)\end{array}$ & $\begin{array}{c}0.001 \\
(0.001)\end{array}$ & $\begin{array}{c}0.002 * * * \\
(0.000)\end{array}$ & $\begin{array}{c}0.002 * * \\
(0.001)\end{array}$ & $\begin{array}{c}0.002 * * * \\
(0.000)\end{array}$ & $\begin{array}{c}0.002 * * \\
(0.001)\end{array}$ \\
\hline Observations & 3,741 & 3,734 & 3,591 & 3,584 & 3,443 & 3,436 \\
\hline R-squared & 0.3479 & 0.3545 & 0.3508 & 0.3580 & 0.3476 & 0.3539 \\
\hline F statistic & 76.20 & 56.39 & 74.07 & 54.94 & 70.00 & 51.71 \\
\hline
\end{tabular}

Note: Standard errors in parentheses

* significant at 10\%; ** significant at 5\%; *** significant at $1 \%$

Sector controls included 
Table 6: $\quad$ Wage Dispersion Models

\begin{tabular}{|c|c|c|c|}
\hline Variable & OLS 70\% & OLS $80 \%$ & OLS $90 \%$ \\
\hline Constant & $\begin{array}{c}-1.239 * * * \\
(0.192)\end{array}$ & $\begin{array}{c}-1.186 * * * \\
(0.183)\end{array}$ & $\begin{array}{c}-1.166^{* * * *} \\
(0.186)\end{array}$ \\
\hline Average Experience & $\begin{array}{c}0.011 * * * \\
(0.004)\end{array}$ & $\begin{array}{c}0.011 * * * \\
(0.004)\end{array}$ & $\begin{array}{c}0.011^{* *} \\
(0.004)\end{array}$ \\
\hline Share of Part-Time Workers & $\begin{array}{c}-0.003 * \\
(0.002)\end{array}$ & $\begin{array}{c}-0.003 * * \\
(0.002)\end{array}$ & $\begin{array}{c}-0.003 * \\
(0.002)\end{array}$ \\
\hline Share of Junior Cert Quals & $\begin{array}{c}0.018 * * * \\
(0.002)\end{array}$ & $\begin{array}{c}0.018 * * * \\
(0.002)\end{array}$ & $\begin{array}{c}0.018 * * * \\
(0.002)\end{array}$ \\
\hline Share of Leaving Cert Quals & $\begin{array}{c}0.026 * * * \\
(0.002)\end{array}$ & $\begin{array}{c}0.025 * * * \\
(0.002)\end{array}$ & $\begin{array}{c}0.025 * * * \\
(0.002)\end{array}$ \\
\hline Share of Post Leaving Cert Quals & $\begin{array}{c}0.019 * * * \\
(0.002)\end{array}$ & $\begin{array}{c}0.019 * * * \\
(0.002)\end{array}$ & $\begin{array}{c}0.019 * * * \\
(0.002)\end{array}$ \\
\hline Share of Third-Level No Degree & $\begin{array}{c}0.026 * * * \\
(0.002)\end{array}$ & $\begin{array}{c}0.025^{* * *} * \\
(0.002)\end{array}$ & $\begin{array}{c}0.025 * * * \\
(0.002)\end{array}$ \\
\hline Share of Graduates & $\begin{array}{c}0.031 * * * \\
(0.002)\end{array}$ & $\begin{array}{c}0.030 * * * \\
(0.002)\end{array}$ & $\begin{array}{c}0.030 * * * \\
(0.002)\end{array}$ \\
\hline Individual-level Agreement & $\begin{array}{c}0.026 \\
(0.090)\end{array}$ & $\begin{array}{c}0.033 \\
(0.087)\end{array}$ & $\begin{array}{c}0.027 \\
(0.087)\end{array}$ \\
\hline Business-level Agreement & $\begin{array}{c}0.059 \\
(0.135)\end{array}$ & $\begin{array}{c}-0.003 \\
(0.133)\end{array}$ & $\begin{array}{c}-0.046 \\
(0.135)\end{array}$ \\
\hline Industry-level Agreement & $\begin{array}{c}-0.232 * \\
(0.128)\end{array}$ & $\begin{array}{c}-0.212 * \\
(0.130)\end{array}$ & $\begin{array}{c}-0.219 * \\
(0.135)\end{array}$ \\
\hline National-level Agreement & $\begin{array}{l}-0.161 * \\
(0.093)\end{array}$ & $\begin{array}{l}-0.168 * \\
(0.091)\end{array}$ & $\begin{array}{l}-0.161 * \\
(0.092)\end{array}$ \\
\hline Other Type of Agreement & $\begin{array}{c}0.136 \\
(0.187)\end{array}$ & $\begin{array}{c}0.105 \\
(0.185)\end{array}$ & $\begin{array}{c}0.115 \\
(0.186)\end{array}$ \\
\hline Average Shift-work & $\begin{array}{c}-0.441 * * * \\
(0.142)\end{array}$ & $\begin{array}{c}-0.494 * * * \\
(0.138)\end{array}$ & $\begin{array}{c}-0.502 * * * \\
(0.141)\end{array}$ \\
\hline Average Professional Body & $\begin{array}{c}1.156^{* * * *} \\
(0.176)\end{array}$ & $\begin{array}{c}1.068 * * * \\
(0.173)\end{array}$ & $\begin{array}{c}1.045 * * * \\
(0.174)\end{array}$ \\
\hline FDI & $\begin{array}{c}0.476 * * * \\
(0.114)\end{array}$ & $\begin{array}{c}0.443 * * * \\
(0.109)\end{array}$ & $\begin{array}{c}0.344 * * * \\
(0.112)\end{array}$ \\
\hline Firm Size & $\begin{array}{c}0.421 * * * \\
(0.037)\end{array}$ & $\begin{array}{c}0.408 * * * \\
(0.037)\end{array}$ & $\begin{array}{c}0.415 * * * \\
(0.038)\end{array}$ \\
\hline Trade Union Density & $\begin{array}{c}-0.003 * * \\
(0.001)\end{array}$ & $\begin{array}{c}-0.003 * \\
(0.001)\end{array}$ & $\begin{array}{c}-0.002 * \\
(0.001)\end{array}$ \\
\hline $\begin{array}{l}\text { Observations } \\
\text { R-squared } \\
\text { F statistic }\end{array}$ & $\begin{array}{c}3,454 \\
0.1737 \\
25.72 \\
\end{array}$ & $\begin{array}{c}3,306 \\
0.1764 \\
27.01 \\
\end{array}$ & $\begin{array}{c}3,161 \\
0.1745 \\
25.48 \\
\end{array}$ \\
\hline
\end{tabular}

Note: Standard errors in parentheses

* significant at 10\%; ** significant at 5\%; *** significant at $1 \%$

Sector controls included 
Table 7: $\quad$ Average Labour Cost Models with FDI Interactions

\begin{tabular}{|c|c|c|c|}
\hline Variable & $\begin{array}{r}\text { Adjusted } \\
\text { OLS 70\% } \\
\end{array}$ & $\begin{array}{l}\text { Adjusted } \\
\text { OLS 80\% } \\
\end{array}$ & $\begin{array}{l}\text { Adjusted } \\
\text { OLS 90\% } \\
\end{array}$ \\
\hline Constant & $\begin{array}{c}2.316 * * * \\
(0.184)\end{array}$ & $\begin{array}{c}2.234 * * * \\
(0.184)\end{array}$ & $\begin{array}{c}2.144 * * * \\
(0.186)\end{array}$ \\
\hline Average Experience & $\begin{array}{c}0.011 * * * \\
(0.002)\end{array}$ & $\begin{array}{c}0.011 * * * \\
(0.002)\end{array}$ & $\begin{array}{c}0.010 * * * \\
(0.002)\end{array}$ \\
\hline Share of Part-Time Workers & $\begin{array}{c}-0.003 * * * \\
(0.000)\end{array}$ & $\begin{array}{c}-0.003 * * * \\
(0.000)\end{array}$ & $\begin{array}{c}-0.003 * * * \\
(0.000)\end{array}$ \\
\hline Share of Junior Cert Quals & $\begin{array}{l}0.001^{*} \\
(0.000)\end{array}$ & $\begin{array}{c}0.001 * * \\
(0.000)\end{array}$ & $\begin{array}{l}0.001^{*} \\
(0.000)\end{array}$ \\
\hline Share of Leaving Cert Quals & $\begin{array}{c}0.003 * * * \\
(0.001)\end{array}$ & $\begin{array}{c}0.003 * * * \\
(0.001)\end{array}$ & $\begin{array}{c}0.003 * * * \\
(0.001)\end{array}$ \\
\hline Share of Post Leaving Cert Quals & $\begin{array}{c}0.001 * * \\
(0.001)\end{array}$ & $\begin{array}{c}0.001 * * \\
(0.001)\end{array}$ & $\begin{array}{c}0.002 * * \\
(0.001)\end{array}$ \\
\hline Share of Third-Level No Degree & $\begin{array}{c}0.005 * * * \\
(0.001)\end{array}$ & $\begin{array}{c}0.005 * * * \\
(0.001)\end{array}$ & $\begin{array}{c}0.005^{* * *} * \\
(0.001)\end{array}$ \\
\hline Share of Graduates & $\begin{array}{c}0.008 * * * \\
(0.001)\end{array}$ & $\begin{array}{c}0.008 * * * \\
(0.001)\end{array}$ & $\begin{array}{c}0.008 * * * \\
(0.001)\end{array}$ \\
\hline Individual-level Agreement & $\begin{array}{c}0.088 * * * \\
(0.021)\end{array}$ & $\begin{array}{c}0.081 * * * \\
(0.021)\end{array}$ & $\begin{array}{c}0.080 * * * \\
(0.021)\end{array}$ \\
\hline Business-level Agreement & $\begin{array}{c}0.0738 * \\
(0.031)\end{array}$ & $\begin{array}{c}0.066 * * \\
(0.032)\end{array}$ & $\begin{array}{c}0.061 * \\
(0.032)\end{array}$ \\
\hline Industry-level Agreement & $\begin{array}{c}0.002 \\
(0.029)\end{array}$ & $\begin{array}{c}0.011 \\
(0.031)\end{array}$ & $\begin{array}{c}0.013 \\
(0.032)\end{array}$ \\
\hline National-level Agreement & $\begin{array}{c}0.027 \\
(0.021)\end{array}$ & $\begin{array}{c}0.021 \\
(0.022)\end{array}$ & $\begin{array}{c}0.020 \\
(0.022)\end{array}$ \\
\hline Other Type of Agreement & $\begin{array}{l}-0.011 \\
(0.044)\end{array}$ & $\begin{array}{l}-0.028 \\
(0.045)\end{array}$ & $\begin{array}{l}-0.032 \\
(0.046)\end{array}$ \\
\hline Average Shift-work & $\begin{array}{c}-0.122 * * \\
(0.054)\end{array}$ & $\begin{array}{c}-0.139 * * * \\
(0.051)\end{array}$ & $\begin{array}{c}-0.155^{* * * *} \\
(0.048)\end{array}$ \\
\hline Average Professional Body & $\begin{array}{c}0.307 * * * \\
(0.066)\end{array}$ & $\begin{array}{c}0.304 * * * \\
(0.078)\end{array}$ & $\begin{array}{c}0.347 * * * \\
(0.081)\end{array}$ \\
\hline Firm Size & $\begin{array}{c}0.091 * * * \\
(0.014)\end{array}$ & $\begin{array}{c}0.095 * * * \\
(0.014)\end{array}$ & $\begin{array}{c}0.093 * * * \\
(0.013)\end{array}$ \\
\hline Trade Union Density & $\begin{array}{l}0.002 * \\
(0.001)\end{array}$ & $\begin{array}{c}0.002 * * \\
(0.001)\end{array}$ & $\begin{array}{c}0.003 * * * \\
(0.001)\end{array}$ \\
\hline \multicolumn{4}{|l|}{ FDI Wage Agreement Interactions: } \\
\hline FDI*Individual-level Agreement & $\begin{array}{c}0.063 \\
(0.072)\end{array}$ & $\begin{array}{c}0.068 \\
(0.073)\end{array}$ & $\begin{array}{c}0.058 \\
(0.074)\end{array}$ \\
\hline FDI*Business-level Agreement & $\begin{array}{l}-0.011 \\
(0.097)\end{array}$ & $\begin{array}{l}-0.015 \\
(0.102)\end{array}$ & $\begin{array}{l}-0.031 \\
(0.105)\end{array}$ \\
\hline FDI*Industry-level Agreement & $\begin{array}{c}0.080 \\
(0.120)\end{array}$ & $\begin{array}{c}0.091 \\
(0.131)\end{array}$ & $\begin{array}{c}0.096 \\
(0.136)\end{array}$ \\
\hline FDI*National-level Agreement & $\begin{array}{c}-0.165 * * \\
(0.075)\end{array}$ & $\begin{array}{c}-0.158 * * \\
(0.077)\end{array}$ & $\begin{array}{c}-0.170 * * \\
(0.079)\end{array}$ \\
\hline FDI*Other Type of Agreement & $\begin{array}{c}0.132 \\
(0.162)\end{array}$ & $\begin{array}{c}0.146 \\
(0.163)\end{array}$ & $\begin{array}{c}0.159 \\
(0.165)\end{array}$ \\
\hline FDI*No Majority & $\begin{array}{c}0.189 * * * \\
(0.067)\end{array}$ & $\begin{array}{c}0.188 * * * \\
(0.067)\end{array}$ & $\begin{array}{c}0.176^{* * * *} \\
(0.068)\end{array}$ \\
\hline
\end{tabular}


Table 7: continued

\begin{tabular}{lccc}
\hline Variable & $\begin{array}{c}\text { Adjusted } \\
\text { OLS 70\% }\end{array}$ & $\begin{array}{c}\text { Adjusted OLS } \\
\mathbf{8 0 \%}\end{array}$ & $\begin{array}{c}\text { Adjusted } \\
\text { OLS 90\% }\end{array}$ \\
\hline Observations & 3,734 & 3,584 & 3,436 \\
R-squared & 0.3573 & 0.3608 & 0.3566 \\
F statistic & 50.07 & 48.76 & 45.89 \\
\hline
\end{tabular}

Note: Standard errors in parentheses

$*$ significant at $10 \%$; * significant at $5 \%$; *** significant at $1 \%$

Sector controls included

Table 8: $\quad$ Bargaining Regime Wage Decomposition for FDI and Indigenous Firms

Decomposition Summary:

Amount Attributable:

46.9

- due to endowments $(E)$ :

23.3

- due to coefficients $(C)$ :

23.6

Shift Coefficient (U):

$-11.1$

Raw Differential (R) $\{\mathrm{E}+\mathrm{C}+\mathrm{U}\}$ :

35.8

Adjusted Differential (D) $\{\mathrm{C}+\mathrm{U}\}$ :

Endowments as a Percentage of Total (E/R):

\section{Detailed Decomposition Information:}

\section{Variable}

Average Experience

Share of Part-Time Workers

Share of Junior Cert Quals

Share of Leaving Cert Quals

Share of Post Leaving Cert Quals

Share of Third-Level No Degree

Share of Graduates

Individual-level Agreement

Business-level Agreement

Industry-level Agreement

National-level Agreement

Other Type of Agreement

Average Shift-work

Average Professional Body

Firm Size

Trade Union Density
Attribute

28.8

1.9

$-2.4$

$-0.7$

$-0.2$

1.4

2.3

$-3.8$

$-1.0$

0.4

$-5.8$

0.5

$-1.6$

2.8

22.7

$-2.1$
Endowment

$-0.6$

8.6

4.3

$-3.4$

$-1.8$

$-3.9$

1.0

$-0.3$

$-0.3$

$-0.4$

$-0.6$

0.1

$-1.4$

2.1

20.4

$-0.1$

23.3
Coefficient

29.4

$-6.6$

$-6.7$

2.6

1.6

5.3

1.4

$-3.5$

$-0.8$

0.9

$-5.3$

0.3

$-0.1$

0.7

2.3

$-2.0$

Sub-total (including sector controls):

46.9

23.6 
Table 9: $\quad$ Wage Dispersion Models with FDI Interactions

\begin{tabular}{|c|c|c|c|}
\hline Variable & OLS 70\% & OLS $80 \%$ & OLS $90 \%$ \\
\hline Constant & $\begin{array}{c}-1.243 * * * \\
(0.188)\end{array}$ & $\begin{array}{c}-1.154 * * * \\
(0.184)\end{array}$ & $\begin{array}{c}-1.133 * * * \\
(0.186)\end{array}$ \\
\hline Average Experience & $\begin{array}{c}0.012 * * * \\
(0.004)\end{array}$ & $\begin{array}{c}0.012 * * * \\
(0.004)\end{array}$ & $\begin{array}{c}0.011 * * * \\
(0.004)\end{array}$ \\
\hline Share of Part-Time Workers & $\begin{array}{c}-0.003 * \\
(0.002)\end{array}$ & $\begin{array}{c}-0.003 * \\
(0.002)\end{array}$ & $\begin{array}{c}-0.003 * \\
(0.002)\end{array}$ \\
\hline Share of Junior Cert Quals & $\begin{array}{c}0.018 * * * \\
(0.002)\end{array}$ & $\begin{array}{c}0.018 * * * \\
(0.002)\end{array}$ & $\begin{array}{c}0.018 * * * \\
(0.002)\end{array}$ \\
\hline Share of Leaving Cert Quals & $\begin{array}{c}0.026 * * * \\
(0.002)\end{array}$ & $\begin{array}{c}0.025 * * * \\
(0.002)\end{array}$ & $\begin{array}{c}0.025 * * * \\
(0.002)\end{array}$ \\
\hline Share of Post Leaving Cert Quals & $\begin{array}{c}0.020 * * * \\
(0.002)\end{array}$ & $\begin{array}{c}0.019 * * * \\
(0.002)\end{array}$ & $\begin{array}{c}0.019 * * * \\
(0.002)\end{array}$ \\
\hline Share of Third-Level No Degree & $\begin{array}{c}0.026 * * * \\
(0.002)\end{array}$ & $\begin{array}{c}0.025 * * * \\
(0.002)\end{array}$ & $\begin{array}{c}0.025 * * * \\
(0.002)\end{array}$ \\
\hline Share of Graduates & $\begin{array}{c}0.031 * * * \\
(0.002)\end{array}$ & $\begin{array}{c}0.030 * * * \\
(0.002)\end{array}$ & $\begin{array}{c}0.030 * * * \\
(0.002)\end{array}$ \\
\hline Individual-level Agreement & $\begin{array}{l}-0.065 \\
(0.093)\end{array}$ & $\begin{array}{l}-0.062 \\
(0.090)\end{array}$ & $\begin{array}{l}-0.056 \\
(0.090)\end{array}$ \\
\hline Business-level Agreement & $\begin{array}{c}-0.084 \\
(0.143)\end{array}$ & $\begin{array}{l}-0.069 \\
(0.140)\end{array}$ & $\begin{array}{l}-0.083 \\
(0.142)\end{array}$ \\
\hline Industry-level Agreement & $\begin{array}{c}-0.308 * * \\
(0.131)\end{array}$ & $\begin{array}{c}-0.295^{* *} \\
(0.134)\end{array}$ & $\begin{array}{c}-0.302 * * \\
(0.138)\end{array}$ \\
\hline National-level Agreement & $\begin{array}{c}-0.214 * * \\
(0.096)\end{array}$ & $\begin{array}{c}-0.221 * * \\
(0.094)\end{array}$ & $\begin{array}{c}-0.212 * * \\
(0.095)\end{array}$ \\
\hline Other Type of Agreement & $\begin{array}{l}-0.055 \\
(0.193)\end{array}$ & $\begin{array}{l}-0.105 \\
(0.192)\end{array}$ & $\begin{array}{l}-0.100 \\
(0.194)\end{array}$ \\
\hline Average Shift-work & $\begin{array}{c}-0.405 * * * \\
(0.139)\end{array}$ & $\begin{array}{c}-0.437 * * * \\
(0.138)\end{array}$ & $\begin{array}{c}-0.460 * * * \\
(0.141)\end{array}$ \\
\hline Average Professional Body & $\begin{array}{c}1.140 * * * \\
(0.176)\end{array}$ & $\begin{array}{c}1.055 * * * \\
(0.172)\end{array}$ & $\begin{array}{c}1.037 * * * \\
(0.174)\end{array}$ \\
\hline Firm Size & $\begin{array}{c}0.433 * * * \\
(0.037)\end{array}$ & $\begin{array}{c}0.417 * * * \\
(0.037)\end{array}$ & $\begin{array}{c}0.423 * * * \\
(0.038)\end{array}$ \\
\hline Trade Union Density & $\begin{array}{l}-0.002 \\
(0.001)\end{array}$ & $\begin{array}{l}-0.002 \\
(0.001)\end{array}$ & $\begin{array}{l}-0.001 \\
(0.001)\end{array}$ \\
\hline \multicolumn{4}{|l|}{ FDI Wage Agreement Interactions: } \\
\hline FDI*Individual-level Agreement & $\begin{array}{c}1.278 * * * \\
(0.310)\end{array}$ & $\begin{array}{c}1.351 * * * \\
(0.302)\end{array}$ & $\begin{array}{c}1.193 * * * \\
(0.303)\end{array}$ \\
\hline FDI*Business-level Agreement & $\begin{array}{c}1.448 * * * \\
(0.418)\end{array}$ & $\begin{array}{c}0.866^{* *} \\
(0.423)\end{array}$ & $\begin{array}{c}0.592 \\
(0.431)\end{array}$ \\
\hline FDI*Industry-level Agreement & $\begin{array}{c}0.780 \\
(0.523)\end{array}$ & $\begin{array}{c}1.004^{*} \\
(0.557)\end{array}$ & $\begin{array}{c}1.084 * \\
(0.570)\end{array}$ \\
\hline FDI*National-level Agreement & $\begin{array}{c}0.400 \\
(0.328)\end{array}$ & $\begin{array}{c}0.418 \\
(0.323)\end{array}$ & $\begin{array}{c}0.427 \\
(0.332)\end{array}$ \\
\hline FDI*Other Type of Agreement & $\begin{array}{c}2.674 * * * \\
(0.698)\end{array}$ & $\begin{array}{c}2.777 * * * \\
(0.677)\end{array}$ & $\begin{array}{c}2.781 * * * \\
(0.677)\end{array}$ \\
\hline FDI*No Majority & $\begin{array}{l}-0.415 \\
(0.267)\end{array}$ & $\begin{array}{l}-0.439 * \\
(0.260)\end{array}$ & $\begin{array}{l}-0.462 * \\
(0.261)\end{array}$ \\
\hline
\end{tabular}


Table 9: continued

Variable

OLS 70\%

OLS 80\%

OLS 90\%

Observations

3,454

3,306

0.1814

0.1850

3,161

R-squared

24.47

23.97

0.1821

Note: Standard errors in parentheses

$*$ significant at $10 \%$;* significant at $5 \%$; ** significant at $1 \%$

Sector controls included 


\section{References}

Aidt, Toke S., and Zafiris Tzannatos. 2008. "Trade Unions, Collective Bargaining and Macroeconomic Performance: A Review." Industrial Relations Journal 39 (4): 258295.

Aust, Andreas. 1999. “The 'Celtic Tiger' and Its Beneficiaries: 'Competitive Corporatism' in Ireland". Paper presented at the ECPR Joint Sessions of Workshops, Mannheim, March 26-31.

Baccaro, Lucio, and Marco Simoni. 2007. "Centralised Wage Bargaining and the “Celtic Tiger” Phenomenon.” Industrial Relations 46 (3), 426-455.

Barrett, Alan, Tim Callan, and Brian Nolan. 1999. "Rising Wage Inequality, Returns to Education and Labour Market Institutions: Evidence from Ireland.” British Journal of Industrial Relations 37 (1): 77-100.

Barrett, Alan, John Fitz Gerald, and Brian Nolan. 2002. "Earnings Inequality, Returns to Education and Immigration into Ireland.” Labour Economics 9 (5): 665-680.

Barry, Frank. 1999. "Irish Growth in Historical and Theoretical Perspective". In Understanding Ireland's Economic Growth, edited by Frank Barry, pp. 25-44. London: Macmillan.

Barry, Frank, John Bradley, and Eoin O’Malley. 1999. "Indigenous and Foreign Industry: Characteristics and Performance". In Understanding Ireland's Economic Growth, edited by Frank Barry, pp. 45-74. London: Macmillan.

Blau, Francine D., and Lawrence M. Kahn. 1986. "International Differences in Male Wage Inequality: Institutions Versus Market Forces." The Journal of Political Economy 104 (4): 791-837.

Blinder, Alan. 1973. "Wage Discrimination: Reduced Forms and Structural Estimates." Journal of Human Resources 8 (4): 436-455. 
Bradley, John, John Fitz Gerald, and Daniel McCoy. 1991. "Medium-Term Review 1991-1996.” (June) Dublin: The Economic and Social Research Institute.

Card, David, Thomas Lemieux and W. Craig Riddell. 2003 "Unions and the Wage Structure." In The International Handbook of Trade Unions, edited by John T. Addison and Claus Schnabel, pp. 246-292. Cheltenham, UK: Edward Elgar.

Card, David, and Sara De La Rica. 2006. "Firm-Level Contracting and the Structure of Wages in Spain.” Industrial and Labour Relations Review 59 (4): 573-592.

Central Statistics Office (CSO). 2007. Census of Industrial Production 2005. Dublin: The Stationary Office.

Department of the Taoiseach. 1987. Programme for National Recovery. Dublin: The Stationery Office.

DiNardo, John, Nicole M. Fortin, and Thomas Lemieux. 1996. "Labor Market Institutions and the Distribution of Wages, 1973-1992: A Semiparametric Approach". Econometrica 64 (5): 1001-1044.

Domínguez, Juan Francisco Canal, and César Rodríguez Gutiérrez. 2004. "Collective Bargaining and Within-firm Wage Dispersion in Spain.” British Journal of Industrial Relations 42 (3): 481-506.

Dustmann, Christian, and Uta Schönberg. 2004. "Training and Union Wages”. IZA Discussion Paper No. 1435 (December). Bonn, Germany: Institute for the Study of Labor.

European Commission. 2003. European Economy, No.6. Belgium: European Commission.

FitzGerald, John. 1999. "Wage Formation and the Labour Market." In Understanding Ireland's Economic Growth, edited by Frank Barry, pp. 137-166. London: Macmillan. 
FitzGerald, John. 2000. "The Story of Ireland's Failure - and Belated Success.” In Bust to Boom? The Irish Experience of Growth and Inequality, edited by Brian Nolan, Philip J. O’Connell and Christopher T. Whelan, pp. 27-57. Dublin: Institute of Public Administration.

Forfás. Various Issues. Annual Employment Survey. Dublin: Forfás.

Forth, John, and Neil Millward. 2002. "Union effects on pay levels in Britain." Labour Economics 9 (4): 547-561.

Freeman, Richard B. 1982. "Union Wage Practices and Wage Dispersion Within Establishments." Industrial and Labour Relations Review 36 (1): 3-21.

Freeman, Richard B., and James L. Medoff. 1981. "The Impact of the Percentage Organized on Union and Nonunion Wages". Review of Economics and Statistics 63 (4): 561-572.

Gardeazabal, Javier, and Arantza Ugidos. 2004. "More on Identification in Detailed Wage Decompositions." The Review of Economics and Statistics 86 (4): 1034-1036.

Gerlach, Knut, and Gesine Stephan. 2005. "Wage Distributions by Wage Setting Regime.” IAB Discussion Paper No. 9/2005 (April). Nuremberg, Germany: Institute for Employment Research.

Gunnigle, Patrick and David McGuire. 2001. "Why Ireland? A Qualitative Review of the Factors Influencing the Location of US Multinationals in Ireland with Particular Reference to Labour Issues" The Economic and Social Review 32 (1): 43-67.

Gurtzgen, Nicole. 2006. "The Effect of Firm- and Industry-Level Contracts on Wages - Evidence from Longitudinal Linked Employer-Employee Data.” ZEW Discussion Paper No. 06-082. Mannheim, Germany: Centre for European Economic Research. 
Hardiman, Niamh. 2000. "Social Partnership, Wage Bargaining, and Growth." In Bust to Boom? The Irish Experience of Growth and Inequality, edited by Brian Nolan, Philip J. O'Connell and Christopher T. Whelan, pp. 286-309. Dublin: Institute of Public Administration.

Hartog, Joop, Edwin Leuven, and Coen Teulings. 2002. "Wages and the Bargaining Regime in a Corporatist Setting: The Netherlands." European Journal of Political Economy 18 (2): 317-331.

Kohn, Karsten, and Alexander C. Lembcke. 2007. "Wage Distributions by Bargaining Regime: Lined Employer-Employee Data Evidence from Germany.” 1 (3-4): 247-261.

Lane, Philip. 1998. "Profits and Wages in Ireland, 1987-1996." Journal of the Social and Statistical Society, 27 (5): 223-252.

Leahy, Dermot, and Catia Montagna. 2000. "Unionisation and Foreign Direct Investment: Challenging Conventional Wisdom?” Economic Journal 110 (462):8092.

Lewis, H. Gregg. 1986. Union Relative Wage Effects: A Survey. Chicago: University of Chicago Press.

McGuinness, Seamus, Fran McGinnity and Philip J. O’Connell. 2009. "Changing Returns to Education During a Boom? The Case of Ireland". Forthcoming Labour.

Oaxaca, Ronald. 1973. "Male-Female Wage Differentials in Urban Labour Markets." International Economic Review 14 (3): 693-709.

Oaxaca, Ronald. \& Michael Ransom. (1999). Identification in Detailed Wage Compositions. The Review of Economics and Statistics, 81 (1), 154-157. 
O’Donnell, Rory. 1999. "Social Partnership: Principles, Institutions and Interpretations". In Astonishing Success: Economic Growth and the Labour Market in Ireland, edited by Philip J. O’Connell, pp. 52-70. Geneva: International Labour Organisation.

O’Donnell, Rory. 2008. "The Partnership State: Building the Ship at Sea". In Contesting the State: Lessons from the Irish Case, edited by Maura Adshead, Peader Kirby and Michelle Millar, pp. 73-99. Manchester: Manchester University Press.

Organisation for Economic Cooperation and Development (OECD). 1997. Employment Outlook. Paris: OECD.

Organisation for Economic Cooperation and Development (OECD). 1999. Economic Surveys: Ireland 1999. Paris: OECD.

Organisation for Economic Cooperation and Development (OECD). 2008. Economic Surveys: Ireland 2008. Paris: OECD.

Plasman, Robert, Michael Rusinek, and Francois Rycx. 2007. "Wages and the Bargaining Regime Under Multi-Level Bargaining: Belgium, Denmark and Spain.” European Journal of Industrial Relations 13 (2): 161-180.

Schumacher, Edward. J. 1999. "What Explains Wage Differences Between Union Members and Covered Nonmembers?" Southern Economic Journal 65 (3): 493-512.

Sexton, Jerry J., and Philip J. O’Connell. 1996. Labour Market Studies, Ireland. Luxembourg: European Commission.

Stephan, Gesine, and Knut Gerlach. 2005. "Wage Settlements and Wage Setting: Results from a Multi-Level Model.” Applied Economics 37 (20): 2297-2306

Stewart, Mark B. 1987. "Collective Bargaining Arrangements, Closed Shops and Relative Pay." Economic Journal 97 (385): 140-156. 
Sweeney, Paul. 1998. The Celtic Tiger: Ireland's Economic Miracle Explained. Dublin: Oak Tree Press.

Tansey, Paul. 1998. Ireland at Work: Economic Growth and the Labour Market 19871997. Dublin, Oak Tree Press.

Teague, Paul, and Jimmy Donaghey. 2004. "The Irish Experiment in Social Partnership." In The New Structure of Labour Relations: Tripartism and Decentralization, edited by Harry C. Katz, Wonduck Lee and Joohee Lee, pp. 10-36. Ithaca: Cornell University Press.

Visser, Jelle. 1998. "Two Cheers for Corporatism, One for the Market: Industrial Relations, Wage Moderation and Job Growth in the Netherlands." British Journal of Industrial Relations 36 (2): 269-292.

Visser, Jelle, and Anton Hermerijck. 1997. A Dutch Miracle: Job Growth, Welfare Reform and Corporatism in the Netherlands. Amsterdam: Amsterdam University Press. 
Appendix A

Table A1:

Average Labour Cost Models - Propensity Score Controls

\begin{tabular}{lccc}
\hline & $\begin{array}{c}\text { Adjusted } \\
\text { OLS 70\% }\end{array}$ & $\begin{array}{c}\text { Adjusted } \\
\text { OLS 80\% }\end{array}$ & $\begin{array}{c}\text { Adjusted } \\
\text { OLS 90\% }\end{array}$ \\
\hline Propensity Score Controls: & & & \\
Individual-level Agreement p & -0.263 & 0.004 & 0.198 \\
& $(0.319)$ & $(0.322)$ & $(0.331)$ \\
Business-level Agreement p & -0.764 & -1.255 & -0.438 \\
& $(1.596)$ & $(1.996)$ & $(1.761)$ \\
Industry-level Agreement p & -0.136 & 0.036 & -0.352 \\
National-level Agreement p & $(0.764)$ & $(0.746)$ & $(0.708)$ \\
& $-1.106^{* * *}$ & $-1.096^{* * *}$ & $-0.925^{* *}$ \\
Other Type of Agreement p & $(0.381)$ & $(0.387)$ & $(0.407)$ \\
& $-2.260^{* *}$ & $-2.167^{*}$ & -1.689 \\
Individual-level Agreement psq & $(1.117)$ & $(1.202)$ & $(1.118)$ \\
Business-level Agreement psq & $-0.387^{*}$ & $-0.570^{* *}$ & $-0.647^{* *}$ \\
& $(0.235)$ & $(0.238)$ & $(0.252)$ \\
Industry-level Agreement psq & 2.543 & 5.144 & 2.527 \\
National-level Agreement psq & $(6.798)$ & $(8.397)$ & $(7.413)$ \\
& -0.445 & -0.875 & -0.368 \\
Other Type of Agreement psq & $(1.409)$ & $(1.432)$ & $(1.506)$ \\
& $0.657^{* *}$ & $0.704^{* *}$ & $0.625^{* *}$ \\
\hline
\end{tabular}

Table A2: Average Labour Cost Models with FDI Interactions - Propensity Score Controls

\begin{tabular}{lccc}
\hline & $\begin{array}{c}\text { Adjusted } \\
\text { OLS 70\% }\end{array}$ & $\begin{array}{c}\text { Adjusted } \\
\text { OLS 80\% }\end{array}$ & $\begin{array}{c}\text { Adjusted } \\
\text { OLS 90\% }\end{array}$ \\
\hline Selection Controls: & & & \\
Individual-level Agreement p & -0.217 & 0.031 & 0.192 \\
& $(0.319)$ & $(0.322)$ & $(0.331)$ \\
Business-level Agreement p & -0.383 & -0.843 & 0.062 \\
& $(1.598)$ & $(1.999)$ & $(1.767)$ \\
Industry-level Agreement p & -0.109 & 0.114 & -0.151 \\
National-level Agreement p & $(0.763)$ & $(0.745)$ & $(0.709)$ \\
& $-1.015^{* * *}$ & $-1.029 * * *$ & $-0.876^{* *}$ \\
Other Type of Agreement p & $(0.383)$ & $(0.388)$ & $(0.408)$ \\
& $-1.883^{*}$ & -1.809 & -1.448 \\
Individual-level Agreement psq & $(1.120)$ & $(1.205)$ & $(1.120)$ \\
& -0.361 & $-0.540^{* *}$ & $-0.599^{* *}$ \\
Business-level Agreement psq & $(0.235)$ & $(0.238)$ & $(0.253)$ \\
& 0.000 & 2.308 & -0.337 \\
Industry-level Agreement psq & $(6.839)$ & $(8.438)$ & $(7.472)$ \\
National-level Agreement psq & -0.541 & -1.038 & -0.742 \\
Other Type of Agreement psq & $(1.407)$ & $(1.431)$ & $(1.508)$ \\
& $0.575^{*}$ & $0.646^{* *}$ & $0.577^{*}$ \\
\hline
\end{tabular}




\begin{tabular}{|c|c|c|}
\hline Year & Number & $\begin{array}{l}\text { Title/Author(s) } \\
\text { ESRI Authors/Co-authors Italicised }\end{array}$ \\
\hline 2008 & 265 & $\begin{array}{l}\text { Poverty in Ireland in Comparative European } \\
\text { Perspective } \\
\text { Christopher T. Whelan and Bertrand Maître }\end{array}$ \\
\hline & 264 & $\begin{array}{l}\text { A Hedonic Analysis of the Value of Rail Transport } \\
\text { in the Greater Dublin Area } \\
\text { Karen Mayor, Seán Lyons, David Duffy and Richard } \\
\text { S.J. Tol }\end{array}$ \\
\hline & 263 & $\begin{array}{l}\text { Comparing Poverty Indicators in an Enlarged EU } \\
\text { Christopher T. Whelan and Bertrand Maître }\end{array}$ \\
\hline & 262 & $\begin{array}{l}\text { Fuel Poverty in Ireland: Extent, } \\
\text { Affected Groups and Policy Issues } \\
\text { Sue Scott, Seán Lyons, Claire Keane, Donal } \\
\text { McCarthy and Richard S.J. Tol }\end{array}$ \\
\hline & 261 & $\begin{array}{l}\text { The Misperception of Inflation by Irish Consumers } \\
\text { David Duffy and Pete Lunn }\end{array}$ \\
\hline & 260 & $\begin{array}{l}\text { The Direct Impact of Climate Change on Regional } \\
\text { Labour Productivity } \\
\text { Tord Kjellstrom, R Sari Kovats, Simon J. Lloyd, } \\
\text { Tom Holt, Richard S.J. Tol }\end{array}$ \\
\hline & 259 & $\begin{array}{l}\text { Damage Costs of Climate Change through } \\
\text { Intensification of Tropical Cyclone Activities: } \\
\text { An Application of FUND } \\
\text { Daiju Narita, Richard S. J. Tol and David Anthoff }\end{array}$ \\
\hline & 258 & $\begin{array}{l}\text { Are Over-educated People Insiders or Outsiders? } \\
\text { A Case of Job Search Methods and Over-education } \\
\text { in UK } \\
\text { Aleksander Kucel, Delma Byrne }\end{array}$ \\
\hline & 257 & $\begin{array}{l}\text { Metrics for Aggregating the Climate Effect of } \\
\text { Different Emissions: A Unifying Framework } \\
\text { Richard S.J. Tol, Terje K. Berntsen, Brian C. } \\
\text { O'Neill, Jan S. Fuglestvedt, Keith P. Shine, Yves } \\
\text { Balkanski and Laszlo Makra }\end{array}$ \\
\hline & 256 & $\begin{array}{l}\text { Intra-Union Flexibility of Non-ETS Emission } \\
\text { Reduction Obligations in the European Union } \\
\text { Richard S.J. Tol }\end{array}$ \\
\hline & 255 & $\begin{array}{l}\text { The Economic Impact of Climate Change } \\
\text { Richard S.J. Tol }\end{array}$ \\
\hline
\end{tabular}


Measuring International Inequity Aversion

Richard S.J. Tol

Using a Census to Assess the Reliability of a

National Household Survey for Migration Research:

The Case of Ireland

Alan Barrett and Elish Kelly

Risk Aversion, Time Preference, and the Social Cost of Carbon

David Anthoff, Richard S.J. Tol and Gary W. Yohe

The Impact of a Carbon Tax on Economic Growth and Carbon Dioxide Emissions in Ireland Thomas Conefrey, John D. Fitz Gerald, Laura Malaguzzi Valeri and Richard S.J. Tol

The Distributional Implications of a Carbon Tax in Ireland

Tim Callan, Sean Lyons, Susan Scott, Richard S.J. Tol and Stefano Verde

Measuring Material Deprivation in the Enlarged EU Christopher T. Whelan, Brian Nolan and Bertrand Maître

Marginal Abatement Costs on Carbon-Dioxide Emissions: A Meta-Analysis

Onno Kuik, Luke Brander and Richard S.J. Tol

Incorporating GHG Emission Costs in the Economic Appraisal of Projects Supported by State Development Agencies

Richard S.J. Tol and Seán Lyons

A Carton Tax for Ireland

Richard S.J. Tol, Tim Callan, Thomas Conefrey, John D. Fitz Gerald, Seán Lyons, Laura Malaguzzi Valeri and Susan Scott

Non-cash Benefits and the Distribution of Economic Welfare

Tim Callan and Claire Keane

Scenarios of Carbon Dioxide Emissions from Aviation

Karen Mayor and Richard S.J. Tol

The Effect of the Euro on Export Patterns:

Empirical Evidence from Industry Data

Gavin Murphy and Iulia Siedschlag 

Competencies Among Higher Education Graduates in Ireland

Elish Kelly, Philip O Connell and Emer Smyth

European Climate Policy and Aviation Emissions Karen Mayor and Richard S.J. Tol

Aviation and the Environment in the Context of the EU-US Open Skies Agreement

Karen Mayor and Richard S.J. Tol

Yuppie Kvetch? Work-life Conflict and Social Class in Western Europe

Frances McGinnity and Emma Calvert

Immigrants and Welfare Programmes: Exploring the Interactions between Immigrant Characteristics, Immigrant Welfare Dependence and Welfare Policy

Alan Barrett and Yvonne McCarthy

How Local is Hospital Treatment? An Exploratory Analysis of Public/Private Variation in Location of Treatment in Irish Acute Public Hospitals Jacqueline OReilly and Miriam M. Wiley

The Immigrant Earnings Disadvantage Across the Earnings and Skills Distributions: The Case of Immigrants from the EU's New Member States in Ireland

Alan Barrett, Seamus McGuinness and Martin OBrien

Europeanisation of Inequality and European Reference Groups

Christopher T. Whelan and Bertrand Maître

Managing Capital Flows: Experiences from Central and Eastern Europe Jürgen von Hagen and Iulia Siedschlag

ICT Diffusion, Innovation Systems, Globalisation and Regional Economic Dynamics: Theory and Empirical Evidence Charlie Karlsson, Gunther Maier, Michaela Trippl, lulia Siedschlag, Robert Owen and Gavin Murphy Interconnection between Great Britain and Ireland Laura Malaguzzi Valeri 
Is FDI into China Crowding Out the FDI into the European Union?

Laura Resmini and lulia Siedschlag

Estimating the Economic Cost of Disability in Ireland

John Cullinan, Brenda Gannon and Seán Lyons

Controlling the Cost of Controlling the Climate: The Irish Government's Climate Change Strategy

Colm McCarthy, Sue Scott

The Impact of Climate Change on the Balanced-

Growth-Equivalent: An Application of FUND

David Anthoff, Richard S.J. Tol

Changing Returns to Education During a Boom?

The Case of Ireland

Seamus McGuinness, Frances McGinnity, Philip

OConnell

'New' and 'Old' Social Risks: Life Cycle and Social Class Perspectives on Social Exclusion in Ireland Christopher T. Whelan and Bertrand Maître

The Climate Preferences of Irish Tourists by Purpose of Travel

Seán Lyons, Karen Mayor and Richard S.J. Tol

A Hirsch Measure for the Quality of Research Supervision, and an Illustration with Trade Economists

Frances P. Ruane and Richard S.J. Tol

Environmental Accounts for the Republic of Ireland: 1990-2005

Seán Lyons, Karen Mayor and Richard S.J. Tol

Assessing Vulnerability of Selected Sectors under Environmental Tax Reform: The issue of pricing power

J. Fitz Gerald, M. Keeney and S. Scott

Climate Policy Versus Development Aid Richard S.J. Tol

Exports and Productivity - Comparable Evidence for 14 Countries

The International Study Group on Exports and Productivity 
The Public/Private Mix in Irish Acute Public Hospitals: Trends and Implications Jacqueline OReilly and Miriam M. Wiley

Regret About the Timing of First Sexual Intercourse: The Role of Age and Context Richard Layte, Hannah McGee

Determinants of Water Connection Type and Ownership of Water-Using Appliances in Ireland Joe O'Doherty, Seán Lyons and Richard S.J. Tol

Unemployment - Stage or Stigma?

Being Unemployed During an Economic Boom Emer Smyth

The Value of Lost Load Richard S.J. Tol

Adolescents' Educational Attainment and School Experiences in Contemporary Ireland Merike Darmody, Selina McCoy, Emer Smyth

Acting Up or Opting Out? Truancy in Irish Secondary Schools

Merike Darmody, Emer Smyth and Selina McCoy

Where do MNEs Expand Production: Location Choices of the Pharmaceutical Industry in Europe after 1992

Frances P. Ruane, Xiaoheng Zhang

Holiday Destinations: Understanding the Travel Choices of Irish Tourists

Seán Lyons, Karen Mayor and Richard S.J. Tol

The Effectiveness of Competition Policy and the Price-Cost Margin: Evidence from Panel Data Patrick McCloughan, Seán Lyons and William Batt

Tax Structure and Female Labour Market Participation: Evidence from Ireland Tim Callan, A. Van Soest, J.R. Walsh 
This document was created with Win2PDF available at http://www.daneprairie.com. The unregistered version of Win2PDF is for evaluation or non-commercial use only. 